\title{
Michael Osborn. Michael Osborn on Metaphor and Style.
}

\author{
Krisztina Magyar
}

East Lansing, MI: Michigan State University Press, cop. 2018, xxvi, 357 ISBN 9781611862874 (paperback)

The book is a collection of essays that consider metaphor to be preeminent in the study of rhetorical discourse. In addition, the essays reveal their author's intense preoccupation with questions of style. Part 1 gathers updated and extended versions of four pieces that were published independently during the 1960s and 1970s. Part 2 features more recent, previously unpublished works. More than simply publishing seminal writings on metaphor and style in one place, Osborn discusses the place of the essays within his career trajectory as a communication scholar in the United States. Overall, publication of the essays allows Osborn to trace both the evolution and refinement of his conception of what he terms rhetorical metaphor and to show his commitment to working toward a more nuanced understanding of style.

The aim of the first essay, "The Metaphor in Public Address," is to redefine the role of metaphor in public discourse in order to "make its significance more comprehensible" (5). To that end, the author makes an attempt to provide a definition of metaphor that might contribute to our understanding of the emphatically pragmatic work of the rhetorician. Osborn "relocate[s] rhetorical metaphor within audience experience" (22) and rescues it from the narrow confines within which ancient rhetoric placed it - namely, the study of style. Instead of treating metaphor as having a merely decorative function, we should, Osborn argues, recognise its inventional potential - that is, its power to generate ideas. Metaphor, in this view, aids both the speaker's thinking and the listener's interpretation, and "the speech becomes an exercise in exploring the analogical resources of the metaphorical insight" (26).

The second essay in the volume, titled "Archetypal Metaphor in Rhetoric: The Light-Dark Family," is frequently referenced by scholars. In this essay, Osborn identifies essential characteristics that he believes set apart what, in his view, constitutes a specific family of metaphor from other figurative resources: the archetypal metaphor. The essay discusses in turn four "sources of archetypal metaphor": light and darkness, the sun, heat and cold, and the seasonal cycle (63).

In "The Evolution of the Archetypal Sea in Rhetoric and Poetic," Osborn contends that it is possible to detect "the gradual emergence of two separate 
patterns of meaning" (99) for the sea metaphor in the history of poetry and that of public address. This separation of meaning, he argues, makes possible a more profound understanding of the nature of both rhetoric and poetry, and offers some insight into the workings of the rhetorical archetype of the sea.

The fourth essay, "Rhetorical Depiction," focuses on the use of particular stylistic devices with a view to shaping one's perception (142). Osborn finds it important to study rhetorical depiction because, in his view, rhetorical critics cannot, at the present moment, satisfactorily explain "that peculiar fusion" of reason and the imagination that Francis Bacon argued constitutes the essential rhetorical function" (137). The author highlights the need to enhance the potential of criticism so that it can deal more satisfactorily with how depiction works in contemporary rhetoric. He argues that it would be "profitable" to reconsider traditional figures with a view to gaining more insight into how they "advance the various depictive functions" identified previously in the essay (179). However, the author contends, it would be advisable to include in the list of figures "newly identified forms of figuration" (179). Here he has Michael Calvin McGee's influential concept of the ideograph in mind, as well as his own concept of the culturetype, which he discusses at some length in "The Metaphor in Public Address." Ultimately, Osborn's theory of depiction as outlined in the essay erases the distinction between literary and public discourse: in exploring the various functions that he attributes to rhetorical depiction, he discusses two literary works, Steinbeck's The Grapes of Wrath and Harriet Beecher Stowe's Uncle Tom's Cabin.

In the essays included in the second part of the book, the author offers illustrations of how rhetorical metaphor actually works. In "Lessons from Demosthenes," he discusses how the Greek orator used metaphor throughout his career. In "Progeny and Personification: Metaphors of Disease and Rebirth," he explores how the disease metaphor, which he considers to be an instance of "archetypal figuration," (234), has evolved through the centuries. In the essay he also explores in some detail the "rich figurative fabric" (261) of Leni Riefenstahl's Nazi propaganda film "Triumph of the Will." The last essay in the collection, "Space and Power: Vertical and Horizontal Orientations in a Rhetorical Universe," highlights the rhetorical potential of vertical and horizontal spatial orientations in public address by comparing Edmund Burke's use of spatial metaphors with more contemporary uses, among them those of Martin Luther King, Jr. and Barack Obama.

The volume is an ambitious, dedicated and imaginative collection of essays on questions of style and the rhetorical work that metaphor can be capable of performing. It is highly recommended as a resource for both students interested in

Italics by Osborn 
the human rhetorical impulse, and scholars working in various academic disciplines, including communication, cultural and literary studies. Indeed, anyone with the ambition to produce imaginative rhetorical criticism with regard to metaphor is well advised to consult Michael Osborn's fine volume of essays. 